\title{
Influence of medium components and metabolic inhibitors on citric acid production by Penicillium simplicissimum
}

\author{
Andreas Franz, ${ }^{1}$ Wolfgang Burgstaller, ${ }^{2 *}$ Brigitte MÜlleR $^{2}$ and Franz Schinner ${ }^{2}$ \\ ${ }^{1}$ Institute for Water Quality and Waste Management, Technical University of Vienna, Karlsplatz 13, 1040 Wien, \\ Austria \\ ${ }^{2}$ Institute of Microbiology, Technikerstrasse 25, 6020 Innsbruck, Austria
}

(Received 9 December 1992; revised 18 March 1993; accepted 20 April 1993)

\begin{abstract}
Penicillium simplicissimum excreted more than $100 \mathrm{mmol}$ citric acid $\mathrm{l}^{-1}\left[2.9 \mathrm{mmol}\left(\mathrm{g} \mathrm{dry} \mathrm{wt}^{-1} ; 9 \mathrm{~d}\right]\right.$ if an industrial filter dust $(>50 \% \mathrm{ZnO}$ ) providing a high extracellular buffering capacity was present in the medium. A similar specific $\left[2 \mathrm{mmol}\right.$ ( $\mathrm{g} \mathrm{dry} \mathrm{wt}^{-1}$ ], but lower absolute $\left(26 \mathrm{mmol} \mathrm{l}^{-1}\right)$, citric acid excretion occurred in the absence of an extracellular buffer and if amino acids or urea were used as nitrogen source. $P$. simplicissimum excreted no citric acid under conditions where Aspergillus niger produces citric acid (deficiency of trace elements, low $\mathbf{p H}$ and reduced biomass formation). Citric acid excretion by $\boldsymbol{P}$. simplicissimum always paralleled biomass formation and occurred in a pH range between 4 and 7. This indicated that different imbalances of metabolism were responsible for citric acid excretion in $\boldsymbol{A}$. niger and $\boldsymbol{P}$. simplicissimum. However, provided a high extracellular buffering capacity was present, the response of the Penicillium system to different carbon and nitrogen sources was similar to the Aspergillus system. In contrast, the metals iron and copper had virtually no effect on citric acid excretion compared with $A$. niger. Estimation of intracellular citric acid, as well as the effects of the uncoupler 2,4dinitrophenol, and the $\mathrm{H}^{+}$-ATPase inhibitor sodium orthovanadate, led to the conclusion that the buffer-stimulated citric acid efflux was dependent on metabolic energy and an energized plasma membrane, respectively. Despite similarities to the Aspergillus system, a different mechanism for buffer-stimulated citric acid excretion by $\boldsymbol{P}$. simplicissimum seems probable.
\end{abstract}

\section{Introduction}

Organic acid excretion by fungi is a widespread, but still not completely understood phenomenon. In the best known case - citric acid production by Aspergillus niger - a high citric acid production rate is attributed to an 'energy overflow' metabolism, which occurs under conditions of high glycolytic activity (Kubicek \& Röhr, 1986), and limited growth because of reduced respiration (Wallrath et al., 1991, 1992). A decrease in respiration is caused in this system by a deficiency of trace elements, especially manganese, which-among other effects (Kubicek \& Röhr, 1986)-impairs the function of complex I of the respiratory chain (Wallrath et al., 1991, 1992). Additionally, a low extracellular $\mathrm{pH}$ contributes to the unfavourable growth conditions (Kubicek \& Röhr, 1986).

Unlike the Aspergillus system, significant amounts of citric acid can also be excreted by fungi growing at normal rates, in a pH range between 4 and 7 and with

${ }^{*}$ Author for correspondence. Tel. 5122185193 ; fax 5122185199. abundant trace elements. These characteristics apply to the enhanced citric acid excretion by Penicillium simplicissimum in the presence of an industrial filter dust containing more than $50 \%$ zinc oxide (Schinner \& Burgstaller, 1989; Franz et al., 1991). Leaching of metals from filter dusts using fungi is one possibility for recycling these materials (Burgstaller \& Schinner, 1993). The addition of $2.5 \%(\mathrm{w} / \mathrm{v})$ filter dust to the medium led to a high extracellular buffering capacity: $\mathrm{ZnO}+$ $2 \mathrm{H}^{+} \rightarrow \mathrm{Zn}^{2+}+\mathrm{H}_{2} \mathrm{O} \quad(\beta=0 \cdot 38)$. The high extracellular buffering capacity was proved to be one of the main reasons for an enhanced citric acid efflux (W. Burgstaller, A. Zanella \& F. Schinner, unpublished results). In this paper, the Penicillium system is compared to the well known Aspergillus system.

Trace amounts of manganese, zinc and iron decrease citric acid production by $A$. niger, with manganese being the most inhibitory (Röhr et al., 1983; Kubicek \& Röhr, 1986). In P. simplicissimum citric acid excretion occurs in the presence of up to $200 \mathrm{~mm}$-zinc (Schinner \& Burgstaller, 1989) and millimolar amounts of other heavy metals (Burgstaller et al., 1990; W. Burgstaller \& 
H. Strasser, unpublished results). Manganese is able to reduce buffer-stimulated citric acid excretion by $P$. simplicissimum (Franz et al., 1991) but not as strongly as in A. niger (Kisser et al., 1980). A further difference is that $A$, niger produces citric acid in synthetic media only if the extracellular pH is low (Kubicek \& Röhr, 1986), whereas $P$. simplicissimum excretes citric acid in a $\mathrm{pH}$ range between 4 and 7 . Similarities between the two systems are the requirement for a high concentration of a carbon source and a high oxygen demand. However, if aeration is interrupted, citric acid production by $A$. niger is irreversibly repressed (Kubicek et al., 1980), whereas $P$. simplicissimum produces citric acid at an unaltered rate when oxygen supply is resumed (Burgstaller et al., 1992).

In this study, factors which are known to influence the Aspergillus system (carbon and nitrogen sources, presence or absence of metals, inhibition of cytoplasmic protein synthesis) were investigated in the Penicillium system. The transport of citric acid across the plasma membrane of $P$. simplicissimum, dependence on metabolic energy and relationship to the activity of one of the most important enzymes of fungal plasma membrane, the $\mathrm{H}^{+}$-ATPase (Sanders, 1988), were also studied. The latter was investigated because the activity of the $\mathrm{H}^{+}$. ATPase has been connected with the excretion of organic acids in Neurospora crassa (Slayman et al., 1990) and Penicillium cyclopium (Roos \& Slavik, 1987). It had also been suggested that the $\mathrm{H}^{+}$-ATPase of Saccharomyces cerevisiae may be stimulated by an extracellular buffer (Sigler \& Höfer, 1991).

\section{Methods}

Strains. $P$. simplicissimum ( $=P$. janthinellum) (Oudem.) Thom, was isolated from a soil contaminated with heavy metals and identified by the Centraaibureau voor Schimmelcultures. Two strains of $A$. niger were from the Centraalbureau voor Schimmelcultures, The Netherlands (CBS 420.64, CBS 120.49).

Spore suspension. Rye grains $(50 \mathrm{~g})$ washed with distilled water and wetted with $50 \mathrm{ml}$ distilled water were autoclaved at $121^{\circ} \mathrm{C}$, inoculated with $1 \mathrm{ml}$ of a spore suspension and incubated at $30^{\circ} \mathrm{C}$. After $4-6 \mathrm{~d}$ spores were washed off with $0.05 \%$ Tween 80 . Spore suspensions were stored in $50 \%(\mathrm{v} / \mathrm{v})$ glycerol at $-20{ }^{\circ} \mathrm{C}$ (short-term storage) or in liquid nitrogen (long-term storage).

Submerged cultivation. Flasks $(500 \mathrm{ml}$ ) containing $70 \mathrm{ml}$ medium or $100 \mathrm{ml}$ flasks containing $20 \mathrm{ml}$ medium were inoculated with a spore suspension to provide a final concentration of $5 \times 10^{7}$ spores $\mathrm{ml}^{-1}$ and incubated at $30^{\circ} \mathrm{C}$ and 150 r.p.m. The standard medium contained (mM): sucrose, $439 ; \mathrm{NH}_{4} \mathrm{NO}_{3}, 25 ; \mathrm{MgSO}_{4} .7 \mathrm{H}_{2} \mathrm{O}, 1-8 ; \mathrm{KH}_{2} \mathrm{PO}_{4}, 6.5$. Alternative carbon sources used included (mM): glucose, 300; lactose, 200; acetic acid, 200; citric acid, 438; $\alpha$-ketoglutarate, 200; molasses $2.9 \%(\mathrm{w} / \mathrm{v})$. Alternative nitrogen sources included: $\left(\mathrm{NH}_{4}\right)_{2} \mathrm{CO}_{3}, 12.5$ or $25 \mathrm{~mm} ; \mathrm{NaNO}_{3}, 55 \mathrm{~mm}$; Casamino acids, $0.77 \%(\mathrm{w} / \mathrm{v})$; molasses, $2.7 \%(\mathrm{w} / \mathrm{v})$. The $\mathrm{pH}$ in media without an extracellular buffer was adjusted to 4 or 7 by addition of $\mathrm{HCl}$ and $\mathrm{NaOH}$, respectively. The standard medium was used with and without a solution of trace elements (Franz et al., 1991). Further nutrient media used were C7apek Dox medium, a glucose-tartrate medium ( $275 \mathrm{~mm}$-glucose, $35 \mathrm{~mm}$ diammonium tartrate, $1.6 \mathrm{mM}-\mathrm{KCl}, 1.3 \mathrm{~mm}-\mathrm{MgSO}_{4} \cdot 7 \mathrm{H}_{2} \mathrm{O}, 0.88 \mathrm{~mm}-$ $\mathrm{KH}_{2} \mathrm{PO}_{4}, 0.32 \mathrm{~mm}-\mathrm{FeSO}_{4} .7 \mathrm{H}_{2} \mathrm{O}, 0.1 \mathrm{~mm}-\mathrm{ZnSO}_{4}, \mathrm{pH} 5.6$; modified from Roos \& Slavik, 1987) and a molasses medium (250 g molasses $1^{-1}$, 6. $5 \mathrm{~mm}-\mathrm{KH}_{2} \mathrm{PO}_{4}$ ).

A high extracellular buffering capacity was achieved by adding a filter dust from the converter of a copper works (Montanwerke Brixlegg, Brixlegg, Austria) or $1 \mathrm{M}$-phthalic acid/triethanolamine $\mathrm{pH} 7.5$ to the standard medium. The filter dust consisted of the following metals in the form of oxides $(\mathrm{w} / \mathrm{w}): 59 \% \mathrm{Zn}, 11 \% \mathrm{~Pb}$, $6 \% \mathrm{Sn}, \quad 0.5 \% \mathrm{Cu}, \quad 0.1 \% \mathrm{As}, \quad 0.07 \% \mathrm{Fe}, \quad 0.03 \% \mathrm{Sb}, \quad 0.02 \% \mathrm{Ni}$, $0.004 \% \mathrm{Ag}$. Filter dust $\left(25 \mathrm{~g} \mathrm{t}^{-1}\right)$ or $17 \mathrm{~g}$ zinc oxide $\mathrm{l}^{-1}$ was added to the standard medium. Filter dust and zinc oxide were sterilized separately. A solution of trace elements was added to media supplemented with zinc oxide or phthalic acid/triethanolamine (Franz et al., 1991).

Investigation of physiological parameters. Stock solutions of chloramphenicol and valinomycin were made in methanol, and of cycloheximide, 2,4-dinitrophenol and sodium orthovanadate in double-distilled water. Inhibitors were added on day 3 for non-replacement experiments and when the pellets were suspended in fresh medium for replacement experiments.

The influence of individual metals was tested by adding a single metal ( $50 \mu \mathrm{mol} \mathrm{l}^{-1}$, final concentration) to the standard medium supplemented with zinc oxide and the solution of trace elements (Franz et al., 1991).

Intracellular citric acid was determined by extracting mycelium frozen in liquid nitrogen with perchloric acid according to Smith \& $\mathrm{Ng}$ (1972) and Kubicek \& Röhr (1978).

The short-term influence of sodium orthovanadate on the respiration rate was examined using a Twin Flow respirometer (Cyclobios). A suspension of pellets $(0.5 \mathrm{ml}, 6 \mathrm{~d}$ old $)$ diluted with $5 \mathrm{ml}$ fresh standard medium was used. Oxygen concentrations were measured at a stirring rate of 500 r.p.m. and a temperature of $25^{\circ} \mathrm{C}$.

Replacement technique. Three-day-old pellets were separated from the medium $(70 \mathrm{ml}$ ) by filtration (pore size $25 \mu \mathrm{m}$ ) and washed in $100 \mathrm{ml}$ distilled water and $150 \mathrm{ml}$ fresh medium and incubated for $3 \mathrm{~d}$ in fresh standard medium.

Analytical methods. Zinc was measured by atomic absorption spectrophotometry using standard conditions. Organic acids and sugars were determined by HPLC (column: Aminex HPX 87H cation exchanger with micro guard cation $\mathrm{H}$ precolumn; mobile phase, $5 \mathrm{~mm}$ $\mathrm{H}_{2} \mathrm{SO}_{4}$; flow rate, $0.5 \mathrm{ml} \mathrm{min}^{-1}$; temperature, $30{ }^{\circ} \mathrm{C}$; detection, refractive index detector and $\mathrm{UV}$ detector at $213 \mathrm{~mm}$ ). After ultrafiltration $(10 \mathrm{kDa})$ samples were diluted 1:50 with distilled water.

Biomass concentrations of cultures grown in the presence of filter dust or zinc oxide were calculated from the difference between the weight after drying at $80^{\circ} \mathrm{C}$ for $24 \mathrm{~h}$ and ashing at $500^{\circ} \mathrm{C}$ for $4 \mathrm{~h}$. In the most unfavourable case, the contribution of the biomass ash to the total ash weight was not more than $5 \%$.

Sampling was carried out daily and all values are the mean values of three or four replicates. Standard deviation was normally lower than $5 \%$ and in a few cases between 5 and $10 \%$.

\section{Results and Discussion}

\section{Growth in standard medium}

Generally speaking, most of the total citric acid produced by $A$. niger during a fermentation period is excreted not during the exponential growth phase but during a secondary 'production' phase which is characterized by a low extracellular $\mathrm{pH}$ and a reduced growth rate 


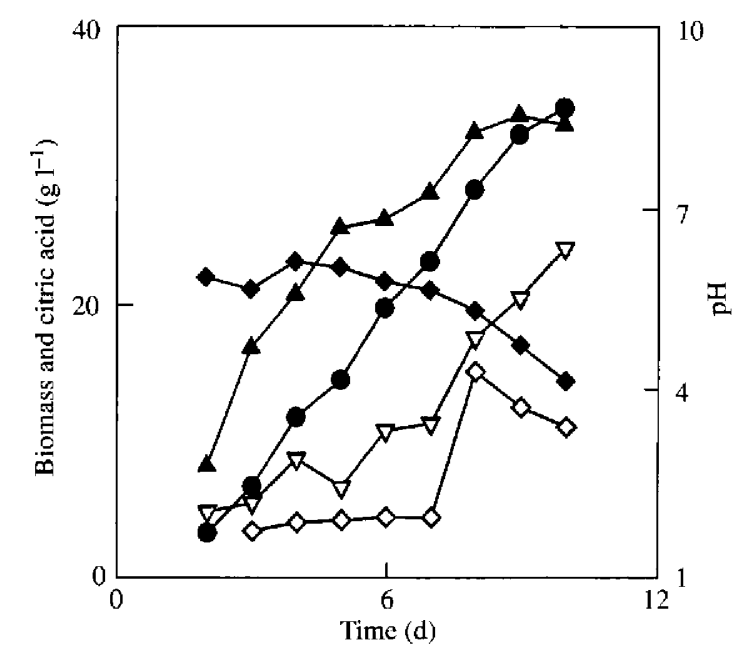

Fig. 1. Course of biomass formation $(\boldsymbol{\Lambda}, \nabla)$ and extracellular $\mathrm{pH}(\bullet$, $\diamond)$ in cultures of $P$. simplicissimum in standard medium with trace elements with (closed symbols) and without (open symbols) filter dust, as well as production of citric acid (O) in the presence of filter dust. Without filter dust no citric acid was produced. Cultivation was carried out in $100 \mathrm{ml}$ flasks containing $20 \mathrm{ml}$ standard medium. Three flasks were sampled each day.

(Chmiel, 1975; Röhr et al., 1983; Steinböck et al., 1991; Wallrath et al., 1992). In contrast, citric acid production by $P$. simplicissimum occurred only in the presence of an industrial filter dust exhibiting a high buffering capacity (Franz et al., 1991), in a $\mathrm{pH}$ range between 4 and 7 (Fig. 1; Schinner \& Burgstaller, 1989) and paralleled the formation of biomass throughout cultivation (Fig. 1). A closer investigation of the mechanism of citric acid excretion in $P$. simplicissimum provided evidence that different imbalances of metabolism were responsible for the excretion of large amounts of citric acid in A. niger and $P$. simplicissimum.

The basic features of growing $P$. simplicissimum in the standard medium without trace elements (the standard medium was a typical citric acid production medium modified after Rehm, 1979; for composition see Methods) were as follows: $P$. simplicissimum strongly acidified this medium during the first $2-3 \mathrm{~d}$ of growth (pH 2 or below). This acidification was stoichiometric (1:1) with the uptake of ammonium. A similar acidification behaviour has been described for $P$. cyclopium in a non-buffered medium with ammonium chloride as nitrogen source (Roos \& Luckner, 1984). P. simplicissinum formed about $2 \mathrm{~g}$ dry wt $\mathrm{l}^{-1}$ during these $3 \mathrm{~d}$.

If the standard medium was supplemented with trace elements, $P$. simplicissimum resumed growth after a short phase of zero growth (Fig. 1). The resumed growth was accompanied by an increase in $\mathrm{pH}$ (Fig. 1).

No organic acids were excreted into the standard medium (with or without trace elements) by $P$. simplicissimum (Table 1). In contrast, two different strains of
Table 1. Stimulation of citric acid excretion in $P$. simplicissimum in a strongly buffered medium

$P$. simplicissimum was cultivated in the standard medium (see Methods) with ammonium nitrate as nitrogen source. The buffers filter dust $\left(\mathrm{ZnO}+2 \mathrm{H}^{+} \rightarrow \mathrm{Zn}^{2+}+\mathrm{H}_{2} \mathrm{O}\right.$ ) or zinc oxide plus trace elements were added as indicated. Flasks $(500 \mathrm{ml})$ with $70 \mathrm{ml}$ of medium were inoculated with $5 \times 10^{7}$ spores $\mathrm{ml}^{-1}$ and incubated at 150 r.p.m. and $30^{\circ} \mathrm{C}$ for $9 \mathrm{~d}$.

\begin{tabular}{|c|c|c|c|c|}
\hline \multirow{2}{*}{$\begin{array}{l}\text { Culture } \\
\text { condition }\end{array}$} & \multicolumn{2}{|c|}{$\mathrm{pH}$} & \multirow{2}{*}{$\begin{array}{c}\text { Biomass } \\
\text { (g dry } \\
\text { wt } 1^{-1} \text { ) }\end{array}$} & \multirow{2}{*}{$\begin{array}{l}\text { Citric acid } \\
{[\mathrm{mmol}} \\
(\mathrm{g} \text { dry } \\
\left.\text { wt })^{-1}\right]\end{array}$} \\
\hline & Start & End & & \\
\hline $\begin{array}{l}\text { Without buffer, } \\
\text { without trace elements }\end{array}$ & $4 \cdot 0$ & $2 \cdot 1$ & $2 \cdot 2$ & 0 \\
\hline $\begin{array}{l}\text { Without buffer, } \\
\text { plus trace elements }\end{array}$ & $4 \cdot 0$ & 60 & $25 \cdot 0$ & 0 \\
\hline $\begin{array}{l}\text { With } 2.5 \%(\mathrm{w} / \mathrm{v}) \text { filter dust, } \\
\text { without trace elements }\end{array}$ & $6 \cdot 5$ & $4 \cdot 5$ & $35 \cdot 1$ & $2 \cdot 9$ \\
\hline $\begin{array}{l}\text { With } 1.7 \%(\mathrm{w} / \mathrm{v}) \text { zinc oxide, } \\
\text { plus trace elements }\end{array}$ & $6 \cdot 5$ & $4 \cdot 7$ & $39 \cdot 7$ & $1 \cdot 8$ \\
\hline
\end{tabular}

Table 2. Influence of nitrogen sources on citric acid excretion in non-buffered cultures of $P$. simplicissimum

P. simplicissimum was cultivated in the standard medium (see Methods) with different nitrogen sources, different concentrations of nitrogen sources and different starting $\mathrm{pH}$ values. No filter dust and no trace elements were added. Flasks $(500 \mathrm{ml})$ with $70 \mathrm{ml}$ of medium were inoculated with $5 \times 10^{7}$ spores $\mathrm{ml}^{-1}$ and incubated at 150 r.p.m. and $30^{\circ} \mathrm{C}$ for $9 \mathrm{~d}$.

\begin{tabular}{|c|c|c|c|c|}
\hline \multirow[b]{2}{*}{ Nitrogen source } & \multicolumn{2}{|c|}{$\mathrm{pH}$} & \multirow{2}{*}{$\begin{array}{c}\text { Biomass } \\
\text { (g dry } \\
\text { wt } 1^{-1} \text { ) }\end{array}$} & \multirow{2}{*}{$\begin{array}{l}\text { Citric acid } \\
{[\mathrm{mmol}} \\
(\mathrm{g} \mathrm{dry} \\
\left.\mathrm{wt})^{-1}\right]\end{array}$} \\
\hline & Start & End & & \\
\hline \multirow[t]{2}{*}{ Urea $(12.5 \mathrm{~mm})$} & $4 \cdot 0$ & 4.0 & $3 \cdot 0$ & $2 \cdot 1$ \\
\hline & $7 \cdot 0$ & $6 \cdot 7$ & 30 & $1 \cdot 3$ \\
\hline \multirow[t]{2}{*}{ Urea $(25 \mathrm{~mm})$} & $4 \cdot 0$ & $4 \cdot 1$ & 1.7 & 0 \\
\hline & $7 \cdot 0$ & $6 \cdot 3$ & $5 \cdot 4$ & 0 \\
\hline \multirow[t]{2}{*}{ Casamino acids } & $4 \cdot 0$ & $2 \cdot 6$ & $12 \cdot 1$ & $2 \cdot 2$ \\
\hline & $7 \cdot 0$ & $4 \cdot 3$ & $12 \cdot 0$ & $1 \cdot 2$ \\
\hline \multirow[t]{2}{*}{ Molasses $[2.7 \%(\mathrm{w} / \mathrm{v})]$} & $4 \cdot 0$ & $4 \cdot 2$ & $26 \cdot 6$ & $0 \cdot 3$ \\
\hline & $7 \cdot 0$ & $5+1$ & $18 \cdot 6$ & 0.5 \\
\hline $\mathrm{NaNO}_{3}(55 \mathrm{~mm})$ & $4 \cdot 0$ & 6.6 & $14 \cdot 5$ & 0.2 \\
\hline \multicolumn{5}{|l|}{ Other media: } \\
\hline Czapek Dox medium & $7 \cdot 0$ & 5.9 & $22 \cdot 2$ & $0 \cdot 4$ \\
\hline Molasses medium & $7 \cdot 0$ & $5 \cdot 9$ & $23 \cdot 0$ & $1 \cdot 2$ \\
\hline
\end{tabular}

A. niger (CBS 420.64 and CBS 120.49) produced up to $100 \mathrm{~mm}$-citric acid after $6 \mathrm{~d}$ when cultivated in this medium (without trace elements; data not shown).

Supplementation of the standard medium with $2.5 \%$ ( $w / v)$ filter dust stimulated the excretion of considerable amounts of citric acid in $P$. simplicissimum cultures (Fig. 1; Table 1). A. niger was not able to grow in the presence of $2.5 \%(\mathrm{w} / \mathrm{v})$ filter dust. It was concluded that the buffering effect of the filter dust $\left(\mathrm{ZnO}+2 \mathrm{H}^{+} \rightarrow\right.$ 


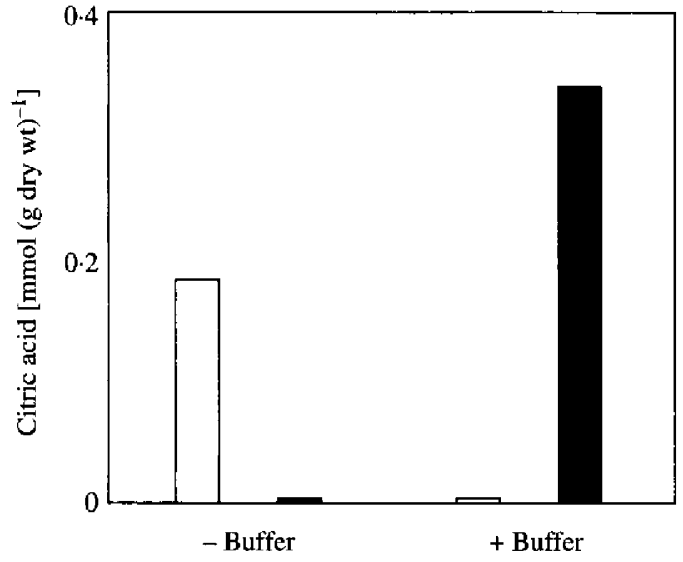

Fig. 2. Influence of the presence of a buffer (1 M-phthalic acid/ triethanolamine, $\mathrm{pH} 7.5$ ) on specific citric acid production by $A$. niger

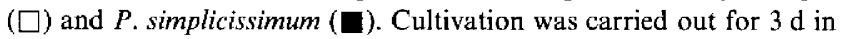
$100 \mathrm{ml}$ flasks containing $20 \mathrm{ml}$ standard medium plus trace elements. Four flasks were sampled each day.

$\mathrm{Zn}^{2+}+\mathrm{H}_{2} \mathrm{O}$ ) rather than a better supply of trace elements in the presence of filter dust was responsible for this enhanced citric acid excretion: the specific citric acid excretion rate in the presence of filter dust was considerably higher than that obtained in Czapek Dox medium which supported similar biomass formation in the absence of a high buffering capacity (Table 2). This conclusion was confirmed by a stimulated citric acid excretion if the standard medium was supplemented with $1 \mathrm{M}$-phthalic acid/triethanolamine, $\mathrm{pH} 7.5$ (Fig. 2) or other buffers (data not shown) instead of filter dust. For $A$. niger the opposite is true: less citric acid is excreted if the medium is buffered compared to the non-buffered low pH medium (Fig. 2; see also Steinböck et al., 1991). The different responses of $A$. niger and $P$. simplicissimum to the extracellular $\mathrm{pH}$ imply different mechanisms for citric acid excretion.

The physiological events leading to the excretion of large amounts of citric acid in A. niger-most important a deficiency of manganese - have been well defined (Kubicek \& Röhr, 1986). For buffer-stimulated citric acid excretion in $P$. simplicissimum only preliminary indications about the effect of an extracellular buffer on the physiology of the cells have been gained. If $P$. simplicissimum was grown in the presence of filter dust, all the filter dust was adsorbed onto the hyphae. Preventing the adsorption of filter dust by packing it into a dialysis bag resulted in lower specific citric acid production and lowered growth rate: $1.7 \mathrm{mmol}$ (g dry $\mathrm{wt}^{-1}$ with adsorbed filter dust and $0.8 \mathrm{mmol}(\mathrm{g} \text { dry wt })^{-1}$ with the filter dust in dialysis bag (day 6; biomass: 43 and $16 \mathrm{gdry} \mathrm{wt}^{-1}$, respectively). The adsorbed filter dust presumably acted as a $\mathrm{pH}$ stabilizer $\mathrm{ZnO}+$ $2 \mathrm{H}^{+} \rightarrow \mathrm{Zn}^{2+}+\mathrm{H}_{2} \mathrm{O}$ ) in the vicinity of the cell surface. Thus the local $\mathrm{pH}$ was increased in comparison to normal conditions (Sentenac et al., 1989). In S. cerevisiae a higher extracellular $\mathrm{pH}$ also resulted in a higher growth rate which was closely correlated to an increased activity of the plasma membrane $\mathrm{H}^{+}$-ATPase (Portillo \& Serrano, 1989). That such a causal chain of events is also probable for increased growth rate of $P$. simplicissimum cultures with adsorbed filter dust is supported by the effect of the plasma membrane $\mathrm{H}^{+}$-ATPase inhibitor vanadate (see below). The filter dust in the dialysis bag could obviously not act as a pH stabilizer in the vicinity of the cell surface and this resulted in a lower growth rate.

\section{Influence of the nitrogen source}

Ammonium is the most widely used nitrogen source for citric acid production in A. niger (Röhr et al., 1983; Kubicek \& Röhr, 1986), although Xu et al. (1989a) found that urea was the best nitrogen source, followed by yeast extract, peptones, ammonium sulphate, malt extract and sodium or ammonium nitrate. In cultures of $P$. simplicissimum without filter dust and with ammonium nitrate as nitrogen source no citric acid was excreted (Table 1). If ammonium nitrate was replaced by urea or Casamino acids, citric acid excretion was observed (Table 2). Both the specific and absolute citric acid excretion were significantly lower compared to that in media with added filter dust. Absolute amounts of excreted citric acid were lower due to lower biomass formation in these media (presumably due to the lack of trace elements). At least for urea the mechanism underlying citric acid excretion seemed to be different from the bufferstimulated citric acid efflux: whereas the latter was proportional to the amount of buffer present in the medium (Schinner \& Burgstaller, 1989), a decrease in the concentration of urea increased citric acid excretion (Table 2).

With $A$. niger sodium nitrate was as effective as ammonium nitrate for citric acid production (Xu et al., $1989 a$ ). With $P$. simplicissimum sodium nitrate as nitrogen source in the absence of filter dust led to a small citric acid efflux whereas ammonium nitrate did not (Tables 1 and 2). Nitrate is taken up by fungi via a proton symport (Sanders, 1988). Thus a $\mathrm{pH}$ stabilizing effect through the uptake of nitrate similar to the one assumed with filter dust can be anticipated. However, $P$. simplicissimum could not grow on sodium nitrate in the presence of filter dust. A reduced amount of protons available for proton symports in this case could explain this finding.

\section{Influence of the carbon source}

Both glucose and sucrose led to very similar levels of citric acid excretion by $P$. simplicissimum in the presence of filter dust. For A. niger sucrose is a better carbon 


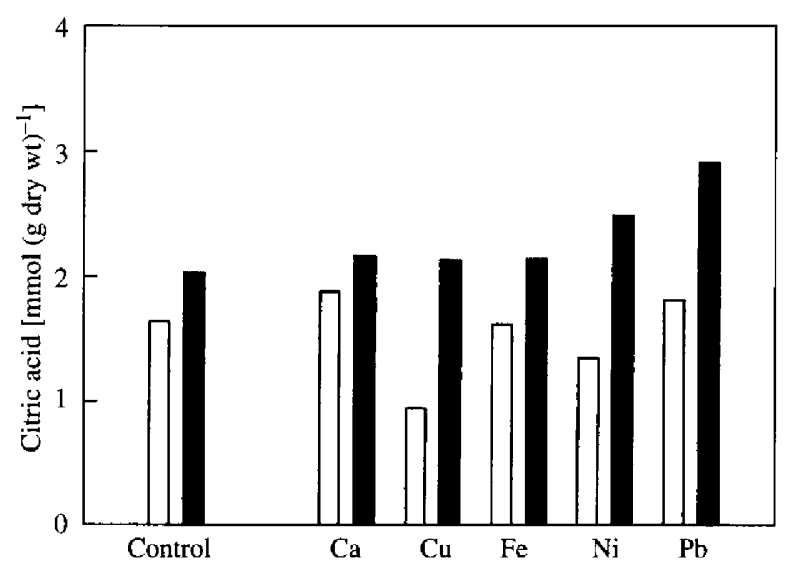

Fig. 3. Influence of trace metals and heavy metals $\left(50 \mu \mathrm{mol} \mathrm{l}^{-1}\right.$ final concentration) on buffer-stimulated specific citric acid excretion by $P$. simplicissimum. Cultivation was carried out in $100 \mathrm{ml}$ flasks containing $20 \mathrm{ml}$ standard medium plus trace elements. Four flasks were sampled on day $3(\square)$ and day 4 (ם).

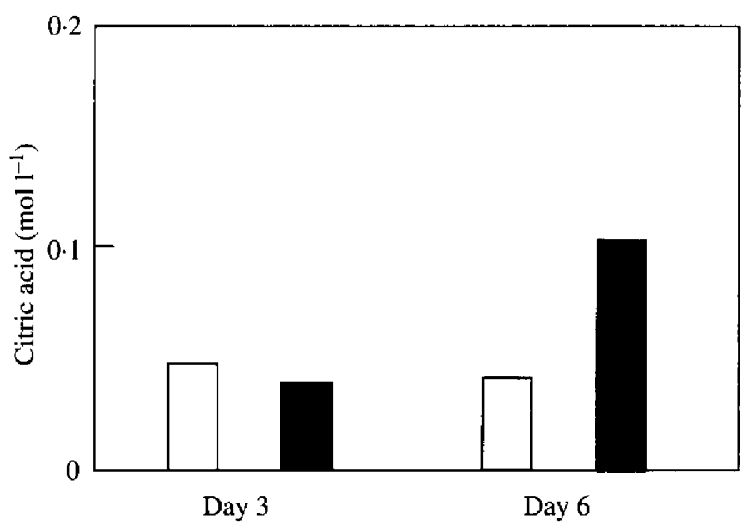

Fig. 4. Intracellular ( $\square$ ) and extracellular ( $\square$ ) citric acid in $P$. simplicissimum cultivated in standard medium with added filter dust. Intracellular citric acid in cultures without filter dust (glucose-tartrate medium) was below the detection limit.

source than glucose (Hossain et al., 1984; Xu et al., $1989 b$ ).

Using acetate, lactose, $\alpha$-ketoglutarate, and citrate as sole carbon sources for $P$. simplicissimum cultures in the presence and absence of filter dust gave similar results to that observed in $A$. niger (Xu et al., 1989b). Acetate could not be used by either fungus. P. simplicissimum and $A$. niger (Xu et al., $1989 b$ ) are able to utilize lactose but neither $A$. niger nor filter dust supplemented cultures of $P$. simplicissimum produced citric acid with lactose. Growth of $P$. simplicissimum on $\alpha$-ketoglutarate and citrate in the presence of filter dust indicated an undisturbed function of the tricarboxylic acid cycle in the presence of heavy metals. These results are in accordance with the postulation of Kubicek $(1988 a, b)$ that organic acid excretion is due mainly to a cytosolic overflow rather than to a bottle neck in the tricarboxylic acid cycle.

\section{Influence of metal ions}

The metals zinc (Schinner \& Burgstaller, 1989; Burgstaller et al., 1990) and iron (Fig. 3) do not decrease buffer-stimulated citric acid excretion in $P$. simplicissimum as is the case with $A$. niger (Röhr et al., 1983; Kubicek \& Röhr, 1986). An increase in citric acid excretion in the presence of calcium has also been found for A. niger (Röhr et al., 1983), whereas the effect of lead requires further investigation to test if its addition could be used to increase citric acid excretion by $P$. simplicissimum during leaching processes.

\section{Physiological parameters}

A first step in the investigation of the metabolic changes occurring in the presence of a buffer (filter dust) in $P$. simplicissimum was the estimation of intracellular citric acid in leaching and non-leaching cultures. The intracellular water was taken as $1.5 \mu \mathrm{l}$ (mg dry wt) $)^{-1}(P$. cyclopium; Roos, 1989 ; other values: $2.5 \mu \mathrm{l}$ for A. niger, C. P. Kubicek, personal communication; $3.0 \mu \mathrm{l}$ for $\mathrm{Neo}-$ cosmospora vasinfecta, Budd, $1989 ; 2 \cdot 0 \mu \mathrm{l}$ for Penicillium chrysogenum, Packer et al., 1992). The comparison of intra- and extracellular citric acid at day 6 (Fig. 4) indicated that the excretion of citric acid proceeded against the electrochemical potential gradient of citric acid; this means that metabolic energy must have been used to excrete citric acid. In $A$. niger citric acid excretion is a 'downhill' transport process (Kubicek \& Röhr, 1978; Kubicek et al., 1980). This is an additional indication that the mechanism of buffer-stimulated citric acid excretion in $P$. simplicissimum is different from the one in A. niger.

Two further results are important: (i) if $P$. simplicissimum was cultivated without filter dust (in a glucose-tartrate medium, which was very similar to the standard medium), intracellular citric acid in $P$. simplicissimum was below the detection limit; this means that the presence of filter dust has the same consequence for $P$. simplicissimum as manganese deficiency for $A$. niger, namely an increase in intracellular citric acid concentration; and (ii) intracellular citric acid in filter dust cultures was ten times lower than found in mycelia of $A$. niger during accumulation of citric acid (Kubicek \& Röhr, 1978).

Chloramphenicol, an inhibitor of mitochondrial protein synthesis, did not inhibit buffer-stimulated citric acid efflux in $P$. simplicissimum to a great extent (Table 3). In contrast, cycloheximide, an inhibitor of eukaryotic translation, caused a strong inhibition of citric acid efflux 
Table 3. Influence of metabolic inhibitors on buffer-stimulated citric acid excretion in $P$. simplicissimum

$P$. simplicissimum was cultivated in the standard medium (see Methods) with ammonium nitrate as nitrogen source in the presence of filter dust. The effect of inhibitors was tested either by direct addition of the inhibitor to a 3-d-old culture or after suspending 3-d-old pellets in fresh medium containing the respective inhibitor. Incubation was continued for $3 \mathrm{~d}$ after addition of the inhibitor. Similar results were obtained with both techniques.

\begin{tabular}{|c|c|c|c|c|c|}
\hline $\begin{array}{l}\text { Compounds } \\
\text { added }\end{array}$ & $\begin{array}{l}\text { Culture } \\
\text { age } \\
\text { (d) }\end{array}$ & $\begin{array}{c}\text { Final } \\
\mathrm{pH}\end{array}$ & $\begin{array}{l}\text { Citric } \\
\text { acid } \\
(\mathrm{mM})\end{array}$ & $\begin{array}{l}\text { Citric acid } \\
\text { per unit of } \\
\text { consumed } \\
\text { sugar }\end{array}$ & $\begin{array}{c}\text { Degree of } \\
\text { inhibition } \\
(\%)\end{array}$ \\
\hline $\begin{array}{l}\text { Control (no added } \\
\text { inhibitor) }\end{array}$ & 3 & $4 \cdot 0$ & 121 & $0 \cdot 19$ & \\
\hline $\begin{array}{l}\text { Chloramphenicol } \\
(0.77 \mathrm{~mm})\end{array}$ & 3 & $4 \cdot 3$ & 108 & 0.18 & 5 \\
\hline $\begin{array}{l}\text { Cycloheximide } \\
(0.89 \mathrm{~mm})\end{array}$ & 3 & 6.0 & 24 & 0.07 & 63 \\
\hline $\begin{array}{l}\text { 2,4-Dinitrophenol } \\
\text { (5 mM) }\end{array}$ & 4 & 58 & 26 & 0.04 & 79 \\
\hline $\begin{array}{l}\text { Sodium orthovanadate } \\
(10 \mathrm{~mm})\end{array}$ & 3 & $6 \cdot 1$ & 26 & 0.05 & 74 \\
\hline
\end{tabular}

(Table 3). Although sugar consumption - and therefore overall metabolism - was also reduced by cycloheximide, inhibition of citric acid excretion was nevertheless a specific effect, because the excreted citric acid per unit of consumed sugar was also decreased by cycloheximide (Table 3). Therefore, in P. simplicissimum, as in A. niger, de novo cytoplasmic protein synthesis is necessary for an increased citric acid efflux. The most important cytoplasmic enzyme for citric acid excretion in $A$. niger is pyruvate carboxylase (Jaklitsch et al., 1991; Steinböck et al., 1991).

The fact that dinitrophenol did not significantly lower sugar consumption, but decreased citric acid excretion, supported the conclusion drawn from the estimation of intracellular citric acid concentration, namely that metabolic energy was needed to excrete citric acid. That metabolic energy is needed to excrete an organic acid already present at high concentration in the cell was also found for S. cerevisiae (Borst-Pauwels, 1981).

An involvement of the plasma membrane $\mathrm{H}^{+}$-ATPase in buffer-stimulated citric acid excretion was indicated by the observation that vanadate reduced citric acid excretion specifically: sugar consumption was not reduced to a great extent and oxygen consumption during a short-term respiration test was not reduced by up to $10 \mathrm{~mm}$-vanadate in non-leaching cultures nor by up to 20 mM-vanadate in leaching cultures.

\section{Conclusions}

A variety of extracellular factors may stimulate a fungal hypha to excrete large amounts of citric acid, for instance: (i) a deficiency of trace elements combined with a low extracellular pH (Kubicek \& Röhr, 1986); (ii) the presence of a specific nitrogen source; and (iii) the presence of a (high) extracellular buffering capacity (Roos \& Luckner, 1984). These results show that with $P$. simplicissimum conditions (i) and (ii) did not lead to the excretion of large amounts of citric acid, but condition (iii) did. This and the fact that citric acid excretion was dependent on metabolic energy indicated a different mechanism of citric acid production compared to $A$. niger. Condition (i), which is used to produce citric acid commercially with $A$. niger, cannot be achieved in metal leaching processes (Burgstaller \& Schinner, 1993). Therefore, a more detailed investigation of condition (iii) is of interest. The decrease of citric acid excretion when the activity of the $\mathrm{H}^{+}$-ATPase was reduced by vanadate indicated that one regulatory point concerning condition (iii) must be looked for in the plasma membrane. Additionally, the mutual relationships between the three different environmental conditions and the question of whether there are species-specific effects or not, are of interest for a better understanding of organic acid excretion by fungi. Organic acids are involved, for instance, in modulating the availability of micronutrients for plants (Msaky \& Msanya, 1986), the contamination of disposal sites by solubilized heavy metals (Francis $e t$ al., 1992), weathering and the winning of valuable metals from oxide or silicate ores and industrial secondary raw materials (Burgstaller \& Schinner, 1993).

\section{References}

Borst-PAuwels, G. W. F. H. (1981). Ion transport in yeast. Biochimica et Biophysica Acta 650, 88-127.

BuDD, K. (1989). Role of the membrane potential in the transport of 
zinc by Neocosmospora vasinfecta. Experimental Mycology 13, 356-363.

BURGSTALLER, W, \& SCHINNFR, F. (1993). Leaching of metals with fungi. Journal of Biotechnology 27, 91-116.

Burgstaller, W., Strasser, H., WÖbring, H. \& Schinntr, F. (1990). Biohydrometallurgy: microbial leaching of zinc from secondary raw materials and industrial intermediate products. Metall 9, 840-843.

Burgstaller, W., Strasser, H., Wöbking, H. \& SchinNer, F. (1992). Solubilization of zinc oxide from filter dust with Penicillium simplicissimum: bioreactor leaching and stoichiometry. Environmental Science and Technology 26, 340-346.

CAssio, F. \& LEAO, C. (1991). Low- and high-affinity transport systems for citric acid in the yeast Candida utilis. Applied and Environmental Microbiology 57, 3623-3628.

ChMiel. A. (1975). Kinetic studies on citric acid production by Aspergillus niger. I. Phases of mycelium growth and product formation. Acta Microbiologica Polonica 73, 185-193.

Francis, A. J., Dodge, C. J. \& Gillow, J. B. (1992). Biodegradation of metal citrate complexes and implications for toxic-metal mobility. Nature, London 356, 140-142.

Franz, A., Burgstaller, W. \& Schinner, F. (1991). Leaching with Penicillium simplicissimum: influence of metals and buffers on proton extrusion and citric acid production. Applied and Environmental Microbiology 57, 769-774.

Hossain, M., Brooks, J. D. \& Maddox, I. S. (1984). The effect of the sugar source on citric acid production by Aspergillus niger. Applied Microbiology and Biotechnology 19, 393-397.

JAKLITSCH, W. M., KUBICEK, C. P. \& SCRUTTON, M. C. (1991). Intracellular location of enzymes involved in citrate production by Aspergillus niger. Canadian Journal of Microbiology 37, 823-827.

Kisser, M., Kubicek, C. P. \& RöHr, M. (1980). Influence of manganese on morphology and cell wall composition of Aspergillus niger during citric acid fermentation. Archives of Microbiology 128, 26-33.

KuBICEK, C. P. (1988a). Regulatory aspects of the tricarboxylic acid cycle in filamentous fungi-a review. Transactions of the British Mycological Society 90, 339-349.

KubICEK, C. P. (1988b). The role of the citric acid cycle in fungal organic acid fermentations. Biochemical Society Symposia 54, $113-126$.

Kubicek, C. P. \& RöHR, M. (1978). The role of the tricarboxylic acid cycle in citric acid accumulation by Aspergillus niger. European Journal of Applied Microbiology and Biotechnology 5, 263-271.

KubiceK, C. P. \& RöHR, M. (1986). Citric acid fermentation. CRC Critical Reviews in Biotechnology 3, 331-373.

Kubicek. C. P., Zehentgruber, O., El-KaLAK, H. \& Röhr, M. (1980). Regulation of citric acid production by oxygen: effect of dissolved oxygen tension on adenylate levels and respiration in Aspergillus niger. European Journal of Applied Microbiology and Biotechnology $\mathbf{9}$, 101-115.

MSAKy, J. J. T. \& Msanya, B. M. (1986). The effect of organic acids on micronutrients solubility in soils. Mededelingen van de Facuiteit Landbouwwetenschapen, Rijksuniversiteit Gent 51, 79-93.

Packer, H. L., Keshavarz-Moore, E., Lilly, M. D. \& Thomas, C. R. (1992). Estimation of cell volume and biomass of Penicillium chrysogenum using image analysis. Biotechnology and Bioengineering 39, 384-391.

Portillo, F. \& Serrano, R. (1989). Growth control strength and active site of the yeast plasma membrane ATPase studied by sitedirected mutagenesis. European Journal of Biochemistry 186, 501-507.

ReHM, H.-J. (1979). Industrielle Mikrobiologie. Berlin: Springer Verlag.

RöHR, M., KUBICEK, C. P. \& KoMINEK, J. (1983). Citric acid. In Biotechnology, vol. 3, pp. 419-454. Edited by H.-J. Rehm \& G. Reed. Weinheim: Verlag Chemie.

Roos, W. (1989). Kinetic properties, nutrient-dependent regulation and energy coupling of amino-acid transport systems in Penicillium cyclopium. Biochimica et Biophysica Acta 978, 119-133.

Roos, W. \& LUCKNER, M. (1984). Relationship between proton extrusion and fluxes of ammonium ions and organic acids in Penicillium cyclopium. Journal of General Microbiology 130 1007-1014

Roos, W. \& SLAVIK, J. (1987). Intracellular pH topography of Penicillium cyclopium protoplasts. Maintenance of delta $\mathrm{pH}$ by both passive and active mechanisms. Biochimica et Biophysica Acta 899 67-75.

SANDERs, D. (1988). Fungi. In Solute Transport in Plant Cells and Tissues, pp. 106-165. Edited by D. A. Baker \& J. L. Hall. Harlow: Longman Scientific \& Technical.

SChINNER, F. \& Burgstaller, W. (1989). Extraction of zinc from industrial waste by a Penicillitu $\mathrm{sp}$. Applied and Environmental Microbiology 55, 1153-1156.

Sentenac, H., Thibaud, J.-B. \& Grignon, C. (1989). Surface pH, bicarbonate and $\mathrm{H}^{*}$-cotransport coupling in corn roots. In Plant Membrane Transport: the Current Position, pp. 611-614. Edited by J. Dainty, M. I. De Michelis, E. Marre \& F. Rasi-Caldogno. Amsterdam: Elsevier.

SIGLER, K. \& HöFER, M. (1991). Mechanisms of acid extrusion in yeast Biochimica et Biophysica Acta 1071, 375-391.

Slayman, C. L., Kaminski, P. \& Stetson, D. (1990). Structure and function of fungal plasma-membrane ATPases. In Biochemistry of Cell Walls and Membranes in Fungi, pp. 299-316. Edited by P. J. Kuhn, A. P. J. Trinci, M. J. Jung, M. W. Goosey \& L. G. Copping. Berlin: Springer Verlag.

Sмітн, J. E. \& NG, W. S. (1972). Fluorometric determination of glycolytic intermediates and adenylates during sequential changes in replacement culture of Aspergillus niger. Canadian Journal of Microbiology 18, 1657-1664.

Steinböck, F. A., Held, I., Choolun, S., Harmsen, H., Röhr, M., Kubicek-Pranz, E. M. \& Kubicek, C. P. (1991). Regulatory aspects of carbohydrate metabolism in relation to citric acid accumulation by Aspergillus niger. Acta Biotechnologica 11, 571-581.

Wallrath, J., Schmidt, M. \& Weiss, H. (1991). Concomitant loss of respiratory chain NADH:ubiquinone reductase (complex I) and citric acid accumulation in Aspergillus niger. Applied Microbiology and Biotechnology 36, 76-81.

Wallrath, J., Schmidt, M. \& Weiss, H. (1992). Correlation between manganese-deficiency, loss of respiratory chain complex I activity and citric acid production in Aspergillus niger. Archives of Microbiology 158, 435-438.

Xu, D. B., KuBICEK, C. P. \& RÖHR, M. (1989a). A comparison of factors influencing citric acid production by Aspergillus niger grown in submerged culture and on filter paper discs. Applied Microbiology and Biotechnology 30,444 450 .

Xu, D. B., Madrid, C. P., Röhr, M. \& Kubicek, C. P. (1989 b). The influence of type and concentration of the carbon source on production of citric acid by Aspergillus niger. Applied Microbiology and Biotechnology 30, 553-561. 